\title{
Alopesi areatalı hastalarda serum bilirubin, ürik asit ve albumin düzeyleri
}

\section{Serum bilirubin, uric acid and albumin levels in patients with alopecia areata}

\author{
Nihal Altunışık ${ }^{1}$ Dursun Türkmen ${ }^{2}$ D \\ ${ }^{1}$ İnönü Üniversitesi Tıp Fakültesi, Dermatoloji Anabilim Dalı, Malatya, Türkiye \\ ${ }^{2}$ Malatya Eğitim ve Araştırma Hastanesi, Dermatoloji Kliniği, Malatya, Türkiye
}

Öz

Amaç: Alopesi areata (AA), saçlı deride skar bırakmayan kıl kaybı ile karakterize, inflamatuar bir hastalıktır. Son dönemlerde inflamatuar ve otoimmun hastalıkların patogenezinde düşük antioksidan düzeyleri ve oksidatif stresin rol oynadığını gösteren çalışmalar bulunmaktadır. Çalışmadaki amacımız, vücuttaki antioksidan durumu yansıtan serum bilirubin, albümin (Alb) ve ürik asit (ÜA) düzeylerinin alopesi areata etiyopatogenezinde rolünü değerlendirmektir.

Gereç ve Yöntem: Çalışmaya dermatoloji kliniğine başvuran 62 AA hastası ile yaş ve cinsiyet olarak benzer 61 sağlıklı kontrol grubu alındı. Her iki grupta, serum total bilirubin (Tbil), direkt bilirubin (Dbil), indirekt bilirubin (İbil), ÜA ve Alb düzeyleri ölçüldü.

Bulgular: Çalışmaya 62 alopesi areata hastası (50 erkek, 12 kadın) ve 61 kontrol hastası (48 erkek, 13 kadın) dahil edildi. İki grup arasında yaş ve cinsiyet açısından istatistiksel olarak anlamlı bir fark yoktu. Alopesi areatalı hastalarda serum Tbil, İbil, ÜA ve Alb değerleri kontrol grubuna göre daha düşüktü, fakat istatistiksel olarak anlamlı bir fark yoktu.

Sonuç: Alopesi areatalı hastalarda serum Tbil, İbil, ÜA ve Alb değerlerinin kontrol grubuna göre daha düşük olması bize vücuttaki antioksidan durumu yansıtan serum bilirubin, albümin ve ürik asit düzeylerinin alopesi areata etiyopatogenezinde rolü olabileceğini düşündürmektedir. Bununla birlikte istatistiksel olarak anlamlı düzeyde düşüklük saptanmaması nedeniyle daha geniş olgu serileri içeren çalışmalara intiyaç olduğuna inanmaktayız.

Anahtar Sözcükler: Alopesi areata, bilirubin, ürik asit, serum albümini, antioksidanlar.

\begin{abstract}
Aim: Alopecia areata $(A A)$ is an inflammatory disease, characterized by hair loss with no scar on the scalp. Recently, there have been studies which show that low antioxidant levels and oxidative stress play a role in the pathogenesis of inflammatory and autoimmune diseases. The aim of this study is to assess the role of serum bilirubin, albumin (Alb) and uric acid (UA) levels, which reflect the antioxidant state in the body, on the etiopathogenesis of alopecia areata.

Materials and Methods: Sixty-two AA patients who had admitted to the dermatology clinic, and 61 control subjects with similar age and sex were included in the study. Serum total bilirubin (Tbil), direct bilirubin (Dbil), indirect bilirubin (Ibil), UA and Alb levels were measured in both groups.

Results: Sixty-two alopecia areata patients (50 male, 12 female) and 61 control patients (48 male, 13 female) were included in the study. There was no statistically significant difference between the two groups in terms of age and gender. In patients with AA, serum Tbil, Ibil, UA and Alb values were lower than the control group, but there was no statistically significant difference.
\end{abstract}

\footnotetext{
Yazışma Adresi: Nihal Altunışık

Inönü Üniversitesi Tıp Fakültesi, Dermatoloji Anabilim Dalı,

Malatya, Türkiye

E-mail: ngold2001@yahoo.com

Makalenin Geliş Tarihi: 26.11.2018 Kabul Tarihi: 11.02.2019
} 
Conclusion: Serum Tbil, Ibil, UA and Alb values were lower in patients with AA compared to the control group, suggesting that the serum bilirubin, UA and Alb levels reflecting the antioxidant status in the body may play a role in the etiopathogenesis of $A A$. However, we believe that there is a need for studies involving larger case series because there is no statistically significant decrease.

Keywords: Alopecia areata, bilirubin, uric acid, serum albumin, antioxidants.

\section{Giriş}

Alopesi areata (AA), saçlı deride skar bırakmayan kıl kaybı ile karakterize, inflamatuar, otoimmunite ile sıkı ilişkili bir hastalıktır. Yaşam boyu görülme intimalinin \%1,7-\%2 olduğu düşünülmektedir (1). Hastalığın etiyopatogenezi tam olarak bilinmemekle birlikte kıl follikülleri, T lenfositler aracıığıyla yıkıma uğratılmaktadır (2). Son yıllarda birçok inflamatuar hastalık patogenezinde olduğu gibi alopesi areata patogenezinde de oksidatif stresin rolü olduğu düşünülmektedir (3-5). Oksidatif stres, sağlıklı bireylerdeki oksijen radikalleri ve antioksidan savunma mekanizma arasındaki dengenin radikaller lehine bozulmasıyla oluşur (6).

Bilirubin, hücre içi ortamda lipit peroksidasyonunda antioksidan etki göstermekle birlikte son yıllarda, sitoprotektif, antioksidan ve antiinflamatuar etkileri olduğu üzerinde durulmaktadır (7-9). Ürik asit (ÜA) insanlarda pürin metabolizmasının son ürünüdür. Hücre dışı ortamda; serbest radikalleri uzaklaştırabildiği için güçlü bir antioksidan olarak görev yapar. Aynı zamanda ÜA, bazen pro-oksidan gibi etki gösterir ve hipertansiyon, kalp hastalıkları, diyabet ve metabolik sendrom gibi çeşitli hastalıkların patogenezinde rol oynadığı düşünülmektedir (10). Albumin (Alb) ise vücuttaki birçok fonksiyonuna ek olarak bakır iyonunu bağlayarak bakır iyonuna bağlı lipit peroksidasyonunu inhibe eder. Serum Alb'nin ise hücre dışı sıvılarda antioksidan olarak önemli rolü olduğu düşünülmektedir $(7,11)$. Bu nedenle serum bilirubin, ÜA ve Alb düzeylerinin oksidatif stresi azaltmakla birlikte vücuttaki antioksidan durumun göstergesi olduğu düşünülebilir (12).

Otoimmün hastalıkların etiyopatogenezinde oksidatif stresin rolünü destekleyen çalışmalar bulunmakla birlikte AA patofizyolojisindeki rolü anlaşılamamıştı (2). Bu nedenle çalışmamızda AA ile serum bilirubin, Alb ve ÜA antioksidan düzeyleri arasındaki ilişkinin saptanması amaçlanmıştır.

\section{Gereç ve Yöntem}

Çalışma Helsinki Bildirgesine uygun olarak gerçekleştirildi. İnönü Üniversitesi Klinik Araştırma- lar Etik Kurulu'ndan onay alındı (Protokol No: 2018/28).

Çalışmaya dermatoloji polikliniğine Mart 2018Temmuz 2018 tarihleri arasında başvuran, AA tanısı almış toplam 62 hasta alındı. Kontrol grubuna ise hastanemize başvuran ve herhangi bir sistemik hastalığı olmayan, yaş ve cinsiyet olarak hasta grubuna benzer 61 sağlıklı gönüllü dâhil edildi.

Sigara veya alkol kullananlar, örneklemden önceki iki haftada topikal veya dört haftada sistemik tedavi kullananlar, gebe veya laktasyonda olanlar, kronik inflamatuar hastalık hikayesi olanlar ve 18 yaş altı hastalar çalışmaya alınmadı.

Tüm hastalar için yaş, cinsiyet, hastalık süresi, lezyonların sayı ve lokalizasyonu, hastalık şiddeti gibi demografik ve klinik bilgileri içeren anket formu dolduruldu. Kavak ve ark.'nın çalışmalarında kullanmış olduğu sınıflamaya göre hastalık şiddeti belirlendi (13). Alopesi totalis ya da universalis "şiddetli", üçten fazla alopesi odağı ya da $3 \mathrm{~cm}$ 'den geniş çaplı yama varlığı "orta", 3 cm ya da daha az çaplı üç ya da daha az lezyon veya kaş ve kirpik tutulumu "hafif" olarak sınıflandırıldı.

İstatistiksel değerlendirmede SPSS (SPSS for Windows, Version 20,0, SPSS Inc, U.S.A) paket programı kullanıldı. Sonuçlar ortalama \pm SD olarak ifade edildi. Tüm istatistiksel testler iki yönlü idi ve istatistiksel anlamlılık $p<0,05$ olarak belirlendi. AA ve sağlıklı kontrol grubundaki serum bilirubin, ÜA ve Alb konsantrasyonları Mann-Whitney $U$ testi kullanılarak karşılaştırıldı. Verilerin normal dağılımı ise KolmogorowSmirnov testiyle değerlendirildi.

\section{Bulgular}

Altmış iki hastanın 12 (\%19,4)'si kadın, 50 $(\% 80,6)$ 'si erkekti. Hastaların yaş ortalaması $33,16 \pm 12,24$ (18-67) idi. Kontrol grubu olarak 61 sağlıklı gönüllü alındı. Bunların 13 (\%21,3)'ü kadın, $48(\% 78,7)$ 'i erkekti ve yaş ortalaması $33,97 \pm 12,21$ (18-62) olarak saptandı. Hasta ve kontrol grubunun demografik ve klinik özellikleri değerlendirildi. $45(\% 72,6)$ olguda hafif, 17 $(\% 27,4)$ olguda ise orta şiddette alopesi areata 
saptandı. Çoğu olgunun hastalık süresi bir yıldan kısa $(\% 75,8)$, en çok etkilenen alan ise saçlı deriydi $(\% 54,8)$ (Tablo-1). AA'lı hasta grubundaki ÜA, Tbil, Dbil, İbil ve Alb düzeyleri kontrol grubu ile karşılaştırıldı ve istatistiksel olarak anlamlı bir fark saptanmadı $(p>0,05) \quad($ Tablo-2). AA ve sağlıklı kontrol grubu cinsiyetlere göre karşılaştırıldığında ise değerlerde yine istatistiksel olarak bir fark bulunmadı. Cinsiyetler arasında yapılan karşılaştırmada; hasta grubunda ÜA ve Alb düzeyleri, sağlıklı kontrol grubunda ise sadece ÜA değerleri kadınlarda erkeklere göre istatistiksel olarak anlamlı düzeyde düşük bulundu (Tablo-2). Hastalık şiddetine göre yapılan karşılaştırmada hafif ve orta şiddetli grup arasında tüm değerlerde istatistiksel fark saptanmadı. Çalışmamızda ağır şiddetli grubuna giren hasta yoktu. Orta şiddetli olgularla sağlıklı kontrol grubu karşılaştırıldığında da benzer şekilde istatistiksel fark görülmedi (Tablo-3).

Tablo-1. Hasta ve kontrol grubunun demografik ve klinik özellikleri.

\begin{tabular}{|c|c|c|c|}
\hline & AA & SK & $\mathbf{p}$ \\
\hline \multicolumn{4}{|l|}{ Cinsiyet } \\
\hline Erkek & $50(\% 80,6)$ & $48(\% 78,7)$ & 0,964 \\
\hline Kadın & $12(\% 19,4)$ & $13(\% 21,3)$ & \\
\hline Toplam & 62 & 61 & \\
\hline Yaş (ortalama $\pm S D$ ) (min-max) & $33,16 \pm 12,24(18-67)$ & $33,97 \pm 12,21(18-62)$ & 0,649 \\
\hline \multicolumn{4}{|l|}{ Hastalık Şiddeti } \\
\hline Hafif & $45(\% 72,6)$ & & \\
\hline Orta & $17(\% 27,4)$ & & \\
\hline Şiddetli & 0 & & \\
\hline \multicolumn{4}{|l|}{ Hastalık Süresi } \\
\hline 1 yıldan kısa & $47(\% 75,8)$ & & \\
\hline $1-5$ yıl & $10(\% 16,1)$ & & \\
\hline 5 yıldan uzun & $5(\% 8,1)$ & & \\
\hline \multicolumn{4}{|l|}{ Alopesi Lokalizasyonu } \\
\hline Saçlı deri & $34(\% 54,8)$ & & \\
\hline Sakal & $22(\% 35,5)$ & & \\
\hline Kaş & $1(\% 1,6)$ & & \\
\hline Saç ve sakal & $4(\% 6,5)$ & & \\
\hline Yaygın & $1(\% 1,6)$ & & \\
\hline
\end{tabular}

AA: Alopesi areata SK: Sağlıklı kontrol, Min: minimum, Max: maksimum

Tablo-2. Hasta ve sağlıklı kontrol grubunda ürik asit, bilirubin ve albümin düzeyleri.

\begin{tabular}{|c|c|c|c|c|c|c|c|}
\hline Hastalar & Toplam & Erkek & Kadın & p1 & p2 & p3 & p4 \\
\hline \multicolumn{8}{|l|}{ TBil,mg/dL } \\
\hline $\mathrm{AA}$ & $0,62 \pm 0,24$ & $0,64 \pm 0,25$ & $0,52 \pm 0,18$ & 0,265 & 0,363 & 0,538 & 0,059 \\
\hline SK & $0,69 \pm 0,33$ & $0,72 \pm 0,35$ & $0,57 \pm 0,21$ & & & & 0,139 \\
\hline \multicolumn{8}{|l|}{ DBil,mg/dL } \\
\hline $\mathrm{AA}$ & $0,13 \pm 0,04$ & $0,13 \pm 0,04$ & $0,11 \pm 0,03$ & 0,516 & 0,426 & 0,852 & 0,051 \\
\hline SK & $0,12 \pm 0,05$ & $0,13 \pm 0,05$ & $0,11 \pm 0,03$ & & & & 0,317 \\
\hline \multicolumn{8}{|l|}{ İBil,mg/dL } \\
\hline $\mathrm{AA}$ & $0,49 \pm 0,19$ & $0,51 \pm 0,20$ & $0,41 \pm 0,15$ & 0,191 & 0,258 & 0,503 & 0,084 \\
\hline SK & $0,56 \pm 0,28$ & $0,59 \pm 0,30$ & $0,46 \pm 0,18$ & & & & 0,131 \\
\hline \multicolumn{8}{|l|}{ ÜA,mg/dL } \\
\hline $\mathrm{AA}$ & $5,26 \pm 1,07$ & $5,43 \pm 0,98$ & $4,54 \pm 1,16$ & 0,959 & 0,840 & 0,611 & 0,016 \\
\hline SK & $5,41 \pm 1,50$ & $5,68 \pm 1,47$ & $4,46 \pm 1,24$ & & & & 0,004 \\
\hline \multicolumn{8}{|l|}{ Albumin,g/dL } \\
\hline AA & $4,40 \pm 0,31$ & $4,45 \pm 0,30$ & $4,20 \pm 0,26$ & 0,777 & 0,959 & 0,295 & 0,008 \\
\hline SK & $4,44 \pm 0,30$ & $4,48 \pm 0,30$ & $4,30 \pm 0,25$ & & & & 0,087 \\
\hline
\end{tabular}

TBil: Total Bilirubin, DBil: Direkt Bilirubin, İ.Bil: İndirekt Bilirubin ÜA: Ürik asit

AA: Alopesi Areata, SK: Sağlıklı Kontrol

p1: Hastalar ve sağlıklı kontrol karşılaştırması

p2: Erkek hastalar ve erkek sağlıklı kontrol grubu karşılaştırması

p3: Kadın hastalar ve kadın sağlıklı kontrol grubu karşılaştırması 
p4: Her iki grup içinde erkek ve kadınlar arası karşılaştırma

Tablo-3. Hafif ve orta şiddetli AA hastalarının karşılaştırılması.

\begin{tabular}{lllll}
\hline & Hafif şiddetli $(\mathbf{n}=\mathbf{4 5})$ & Orta şiddetli $(\mathbf{n}=\mathbf{1 7})$ & $\mathbf{P}^{\mathbf{1}}$ değeri & $\mathbf{P}^{\mathbf{2}}$ \\
\hline Tbil & $0,61 \pm 0,26$ & $0,64 \pm 0,19$ & 0,565 & 0,667 \\
Dbil & $0,12 \pm 0,05$ & $0,14 \pm 0,03$ & 0,052 & 0,069 \\
İbil & $0,49 \pm 0,20$ & $0,50 \pm 0,17$ & 0,776 & 0,357 \\
ÜA & $5,26 \pm 1,08$ & $5,24 \pm 1,07$ & 0,868 & 0,975 \\
Albumin & $4,38 \pm 0,31$ & $4,45 \pm 0,31$ & 0,646 & 0,865 \\
\hline
\end{tabular}

TBil: Total Bilirubin, DBil: Direkt Bilirubin, İBil: İndirekt Bilirubin, ÜA: Ürik asit, AA: Alopesi areata,

$\mathrm{P}^{1}$ : hafif ve orta şiddetli olguların birbiriyle karşılaştırıması, $\mathrm{P}^{2}$ : orta şiddetli olgular ile kontrol grubunun karşılaştırıması

\section{Tartışma}

Alopesi areata, inflamasyona bağlı saç kayıplarının en sık nedeni olup, net sınırlı saç kaybı alanlarıyla karakterize otoimmun bir tablodur (1). Etiyopatogenezde genetik yatkınlık, eser element eksiliği, duygusal stres, atopik durum, otoimmun reaksiyonların rolü üzerinde durulmakla birlikte, tam neden bilinmemektedir (2). Son dönemlerde hastalık etiyolojisinde oksidatif stresin rolü üzerinde de durulmaktadır $(4,5)$.

Oksidatif stres reaktif oksijen türevlerinin aşırı üretimi veya yetersiz tüketimi sonucu oluşur ve protein oksidasyonuna, DNA mutasyonu ya da kırılmasına sebep olur (6). Canlı hücrelerde okside olabilecek maddelerin oksidasyonunu önleyen veya geciktirebilen maddelere antioksidan, bu olaya ise antioksidan savunma denir. Süperoksit dismutaz, katalaz ve glutatyon peroksidaz enzimleri insandaki başlıca hücre içi antioksidanlardır. E ve C vitamini, transferrin, albümin, bilirubin ise hücre dışı ortamdaki antioksidan savunmada rol oynar (7).

Alopesi areatada kı folikülü etrafında inflamasyon sonucu ortaya çıkan sitokinler mitokondriyal serbest oksijen türlerinin yapımını uyararak oksidatif stresin artmasına neden olur. Oksidatif stresin yeni antijenik yapıların oluşmasını sağlayarak ve mitokondriyal membran hasarı oluşturarak otoimmuniteyi tetiklediği düşünülmektedir. Ayrıca oksidatif stres sonucu oluşan fazla miktardaki reaktif oksijen türevlerinin hücre apoptozuna neden olarak apoptotik artıkların birikimine yol açtığı ve bu durumun otoimmunitede rolü olduğu kabul edilmektedir. Bununla birlikte otoimmun inflamatuar bir hastalık olan AA'da oksidatif stresin hastalığı başlatan bir etken mi yoksa inflamasyonun sonucu mu olduğu tam olarak anlaşılamamıştır $(3,12)$.
Alopesi etiyopatogenezinde lipit peroksidasyonunun etkisini gösteren ilk çalışma 2000 yılında Naziroğlu ve Kokcam tarafından yapılmıştır. Çalışmada plazma beta karoten, eritrosit ve plazmada glutatyon peroksidaz değerlerinde azalma tespit etmişlerdir (14). Literatürde yapılan diğer bir çalışmada ise $A A^{\prime}$ 'ı hastalarda nitrik oksit gibi oksidan parametrelerin sağlıklı kontrollere göre istatistiksel olarak anlamlı derecede arttığı, superoksit dismutaz gibi antioksidan sistem parametrelerinin ise istatistiksel olarak anlamlı derecede düşük olduğu saptanmıştır (2). Bir başka çalışmada ise AA'lı hasta ve kontrol grubunda serum örneklerinde total antioksidan kapasite (TAK) ve total oksidan kapasite ölçülmüş, oksidatif stres indeksi hesaplanmıştır. Sonuç olarak hasta grubunun TAK değerlerinin kontrol grubuna göre daha yüksek olduğu belirlenmiştir (3).

Reaktif oksijen türevleri alopesi areata dışında; deri kanseri, psoriazis, vitiligo, akne vulgaris, atopik dermatit, liken planus gibi birçok deri hastalığında da etiyolojik faktör olarak rol oynadığı düşünülmekle birlikte etki mekanizmaları tam olarak anlaşılamamıştır (6, $15,16)$.

Literatürde yapılan çalışmalarda, birçok otoimmun hastalık etiyopatogenezinde oksidatif stresin rolünü saptamak için vücuttaki antioksidan durumu yansıtan serum bilirubin, Alb ve ÜA düzeyleri ölçülmüştür (17-19).

Li ve ark. (12) yaptıkları bir çalışmada, pemfigus vulgarisli hastalarla sağlıklı kontrol grubunu karşılaştırmışlar ve pemfiguslu hastalarda kontrol grubuna göre serum bilirubin, Alb ve ÜA düzeylerini istatistiksel olarak anlamlı derecede daha düşük saptamışlardır. Yakın zamanda ülkemizde yapılan bir çalışmada ise vitiligolu hastalar sağlıklı kontrol grubu ile karşılaştırılmış 
ve bilirubin düzeyleri anlamlı derecede düşük saptanırken, ÜA ve Alb düzeyleri bakımından vitiligo ve kontrol grubu arasında istatistiksel olarak anlamlı bir fark tespit edilmemiştir (20).

AA etiyolojisinde antioksidan düzeylerinin ve oksidatif stresin rolünü saptamak için birçok çalışma yapılmış olmakla birlikte vücuttaki antioksidan durumu yansitan parametreler olduğu düşünülen serum bilirubin, ÜA ve Alb düzeylerini değerlendiren bir çalışmaya rastlayamadık. Bu nedenle çalışmamızda AA'ı hastalar ve sağlıklı kontrol grubu serum bilirubin, Alb ve ÜA düzeyleri açısından değerlendirildi. Alopesi areatalı hastalarda serum Tbil, İbil, ÜA ve Alb değerleri kontrol grubuna göre daha düşüktü, fakat istatistiksel olarak anlamlı bir fark yoktu. Cinsiyetler arasında yapılan karşılaştırmada; hasta grubunda ÜA ve Alb düzeyleri, sağlıklı kontrol grubunda ise sadece ürik asit değerleri kadınlarda erkeklere göre istatistiksel olarak anlamlı düzeyde düşük bulundu. Ürik asit ve Alb değerlerinin hem AA hem sağlıklı kontrol grubundaki kadınlarda daha düşük saptanması cinsiyet faktörünün etkisi olarak düşünüldü. Alopesi areatada hastalık şiddetinin vücuttaki antioksidan düzeylerine olan etkisini değerlendirmek için hafif ve orta şiddetli grup karşılaştırıldı fakat tüm değerlerde istatistiksel olarak anlamlı bir fark saptanmadı. Orta şiddetli olgularla sağlıklı kontrol grubu karşılaştırıldığında da benzer şekilde istatistiksel bir fark görülmedi.

\section{Sonuç}

AA'lı hastalarda serum Tbil, İbil, ÜA ve Alb değerlerinin kontrol grubuna göre istatistiksel olarak önemli bir fark gösterilememekle birlikte daha düşük olması bize vücuttaki antioksidan durumu yansıtan serum bilirubin, Alb ve ÜA düzeylerinin alopesi areata etiyopatogenezinde rolü olabileceğini ve bunu daha iyi değerlendirmek için daha geniş olgu serileri içeren çalışmalar intiyaç olduğunu düşündürmektedir.

\section{Kaynaklar}

1. Oğuz O. Alopecia areata. Turkderm-Archives of the Turkish Dermatology and Venerology 2014; 48 (1): 40-4.

2. Heıdarloo KA, Adışen E. Oxidative stress in alopecia areata and its association with disease severity, treatment and autoimmunity. Turkiye Klinikleri J Med Sci 2015; 35 (4): 268-78.

3. Kılınç F, Akbaş A, Yorulmaz A, Şener S, Neşelioğlu S, Erel Ö et al. Etiyopathogenesis and oxidative stress relationship in mild severe alopecia areata. Turk J Dermatol 2017; 11 (3): 114-8.

4. Motor S, Ozturk S, Ozcan O, Gurpinar AB, Can Y, Yuksel R et al. Evaluation of total antioxidant status, total oxidant status and oxidative stress index in patients with alopecia areata. Int J Clin Exp Med 2014; 7 (4): 1089-93.

5. Prie BE, Voiculescu VM, lonescu-Bozdog OB, Petrutescu B, losif L, Gaman LE et al. Oxidative stress and alopecia areata. J Med Life 2015; (8): 43-6.

6. Karaca Ş, Güder H. Antioxidant system in dermatology. Turkish J Dermatology 2009; 3 (2): 32-9.

7. Çavdar C, Sifil A, Çamsarı T. Reactive oxygen particles and antioxidant defence. Office Journal of the Turkish Nephrology, Association 1997; 3 (4): 92-5.

8. Stocker R, Yamamoto Y, McDonagh AF, Glazer AN, Ames BN. Bilirubin is an antioxidant of possible physiological importance. Science 1987; 235 (4792): 1043-6.

9. Liu Y, Li P, Lu J, Xiong W, Oger J, Tetzlaff W et al. Bilirubin possesses powerful immunomodulatory activity and suppresses experimental autoimmune encephalomyelitis. J Immunol 2008; 81 (3): 1887-97.

10. Kumar AN, Aruna P, Naidu JN, Kumar R, Srivastava AK. Review of concepts and controversies of uric acid as antioxidant and pro-oxidant. Archives Medical Review Journal 2015; 24 (1): 19-40.

11. Roche M, Rondeau P, Singh NR, Tarnus E, Bourdon E. The antioxidant properties of serum albumin. FEBS Lett 2008; 582 (13): 1783-7.

12. Li WC, Mo LJ, Shi X, Lin ZY, Li YY, Yang Z et al. Antioxidant status of serum bilirubin, uric acid and albumin in pemphigus vulgaris. Clin Exp Dermatol 2018; 43 (2): 158-63.

13. Kavak A, Baykal C, Ozarmagan G, Akar U. HLA in alopecia areata. Int J Dermatol 2000; 39 (8): 589-92.

14. Naziroglu M, Kokcam I. Antioxidants and lipid peroxidation status in the blood of patients with alopecia.Cell Biochem Funct 2000;18 (3): 169-73.

15. Kılıç A, Erdoğan S, Yorulmaz A, Doğan S, Ergin M, Artüz F et al. The oxidative stress parameters and the effect of dyslipidemia on the parameters of oxidative stress in lichen planus. Turkderm - Arch Turk Dermatol Venerology 2015; 49: (1): 7-12. 
16. Addor FAS. Antioxidants in dermatology. An Bras Dermatol. 2017; 92 (3): 356-62.

17. Fuhua $P$, Xuhui D, Zhiyang Z, Ying J, Yu Y, Feng $T$ et al. Antioxidant status of bilirubin and uric acid in patients with myasthenia gravis. Neuroimmunomodulation 2012; 19 (1): 43-9.

18. Chen Z, Su Z, Pang W, Huang Y, Lin J, Ding Z et al. Antioxidant status of serum bilirubin and uric acid in patients with polymyositis and dermatomyositis. Int J Neurosci 2017; 127 (7): 617-23.

19. Peng F, Yang Y, Liu J, Jiang Y, Zhu C, Deng X et al. Low antioxidant status of serum uric acid, bilirubin and albumin in patients with neuromyelitis optica. Eur J Neurol 2012; 19 (2): 277-83.

20. Türkmen D, Altunışık N. Serum bilirubin, uric acid and albumin antioxidant levels in patients with vitiligo. Turkiye Klinikleri J Dermatol 2018; 28 (2): 63-8. 